\begin{tabular}{|l|l|l||}
\hline \multicolumn{2}{|c|}{ PublisherInfo } \\
\hline \hline PublisherName & $:$ & BioMed Central \\
\hline \hline PublisherLocation & $:$ & London \\
\hline \hline PublisherImprintName & $:$ & BioMed Central \\
\hline \hline
\end{tabular}

\title{
Chromosome replication
}

\begin{tabular}{|l|l|l||}
\hline \multicolumn{2}{|c|}{ ArticleInfo } \\
\hline \hline ArticleID & $:$ & 4220 \\
\hline \hline ArticleDOI & $:$ & $10.1186 /$ gb-spotlight-20011009-01 \\
\hline \hline ArticleCitationID & $:$ & spotlight-20011009-01 \\
\hline \hline ArticleSequenceNumber & $:$ & 291 \\
\hline \hline ArticleCategory & $:$ & Research news \\
\hline ArticleFirstPage & $:$ & 1 \\
\hline \hline ArticleLastPage & $:$ & 2 \\
\hline \hline & & RegistrationDate : 2001-10-09 \\
ArticleHistory & $:$ & OnlineDate \\
\hline \hline ArticleCopyright & $:$ & BioMed Central Ltd2001 \\
\hline \hline ArticleGrants & $:$ & \\
\hline \hline ArticleContext & $:$ & 130592211 \\
\hline \hline
\end{tabular}




\section{Jonathan B Weitzman}

Email: jonathanweitzman@hotmail.com

The initiation of chromosome replication is exquisitely regulated in both time and location. It has been estimated that there are 200-400 autosomal replication sequence elements (ARSs) in the yeast genome that act as replication origins. Although they share some common sequence features, origins are difficult to predict from genomic sequence. In the October 5 Science, Raghuraman et al., from the University of Washington in Seattle, describe a microarray-based approach to investigate the kinetics of replication across the entire budding yeast genome (Science 2001, 294:115-121). They used isotopically dense culture medium to isolate replicated and unreplicated DNA at different points during S phase of the cell cycle, and hybridized the DNA to oligonucleotide microarrays. In this way they could define the replication profile of a chromosome and the time and location of many origins, as well as information about the rate and direction of replication-fork migration. They detected 332 origins in the yeast genome, and some of these correlated well with previously characterized origins. The origins were continuously activated throughout S phase, with the majority occurring in mid-S. Centromeres are replicated earlier than sub-telomeric regions, and replication at the two ends of the same chromosome appears to be coordinated. The fork-migration rates varied considerably (on average $2.3 \mathrm{~kb}$ per minute) and were not always symmetric for lefthand and righthand forks from the same origin. Raghuraman et al.report no correlation between transcription and replication timing. They predict that methodology of this type could be fruitfully applied to analysis of distinct cell-culture conditions or genotypic differences, and could be extended to examine replication across the human genome.

\section{References}

1. Replication fork rate and origin activation during the $\mathrm{S}$ phase of Saccharomyces cerevisiae

2. Science, [http://www.sciencemag.org]

3. University of Washington, [http://www.washington.edu/]

This PDF file was created after publication. 